\title{
Myanmar's Military Dictatorship Continuance: Old Wine in New Bottle
}

\author{
Yu Szu-Tu \\ National Sun Yat-Sen University, Kaohsiung, Taiwan \\ Samuel C. Y. Ku \\ Wenzao Ursuline University of Language, Kaohsiung, Taiwan
}

Since 1962 till 2016, the Myanmar government has mainly been under the leadership of the following four political figures: Ne Win, Saw Maung, Than Shwe, and Thein Sein. However, none of them rose to power through genuine consensus of the nation's people, thus lacking in legitimacy and legality. Against this backdrop, the Myanmar society is incessantly caught in a cycle of tyranny, surveillance, repression and other means of inequality, as military authority continues to be reinforced in the country. Even though Thein Sein led a series of reform which include the release of some political detainees, freedom from house arrest granted to Aung San Suu Kyi, the right to form political parties, and relaxation of media censorship, he was still using military force to control various sectors in Myanmar, with military dictatorship still at the core of his power. General elections were held in Myanmar on November 8, 2015, the first open election since May of 1990. The results were as expected, with the National League for Democracy (NLD) led by Aung San Suu Kyi now holding majorities in the House of Nationalities (with 135 seats) and the House of Representatives (with 255 seats), granting NLD comprehensive governance, with NLD member, U Htin Kyaw, elected as the first Myanmar civilian president in 54 years. Aung San Suu Kyi is to head two cabinet posts including foreign affairs and president's office ministries. However, the path ahead for the Myanmar political climate is still fraught with uncertainties, and it is mainly due to the transparent injustice embedded in the Myanmar constitution, which allows the military regime to continue to hold control over the country, reserving the possibilities for the military to make a comeback. Based on the above, this paper investigates the dictatorship of Ne Win, Saw Maung, Than Shwe, and Thein Sein through political development theory, and the objective is to present evidence that although Myanmar has been through different leaders, they all at the core, have maintained a military dictatorship. Lastly, further analysis is presented on the limitations imposed on the development of democracy in Myanmar due to the terms listed in the current constitution, making it challenging for the current Myanmar government to break free from military control after the 2015 elections, with the situation resembling putting old wine in a new bottle.

Keywords: Myanmar, military dictatorship, constitution

Yu Szu Tu, Post-Doctoral Fellow, Institute of China and Asia-Pacific Studies, National Sun Yat-Sen University. Samuel C. Y. Ku, Vice President for International Affairs, Wenzao Ursuline University of Language. 


\section{Introduction $^{1}$}

Dictatorship is a form of government in which one person possesses absolute power that transcends even constitutional limitations, with monopoly of power that is exercised without constraint. A military dictatorship is where the dictator rules through direct control of the military to systematically implement suppression to hold authoritarian control. In other words, it controls weapons and force, with the military granted director power to interfere with politics and society, and even leading to the forming of government based military control (Heywood, 2009, pp. 574-577).

From 1962 till 2016, Myanmar's government has been through changes in leadership under Ne Win, Saw Maung, Than Shwe, and Thein Sein. However, none of them rose to power through genuine consensus of the nation's people and thus lacking in legitimacy and legality. In 1962, General Ne Win led a military coup d'état, which overthrew $\mathrm{U} \mathrm{Nu}$, ending Myanmar's nearly 14 years of parliamentary and democratic government, and established a dictatorship government with strong military control. With military control, Ne Win dominated Myanmar's political regime for 26 years, and was forced to resign in 1988 after an intense student-led uprising.

With Ne Win's support, General Saw Maung staged a military coup in 1988 and seized control of the government. In power for only four years, the Saw Maung regime stirred worldwide condemnation by refusing to recognize the result for the legislative elections in May 1990 and placing Aung San Suu Kyi under house arrest. With both domestic and international condemnations, Saw Maung was forced to resign in 1992 and handed his leadership power to General Than Shwe.

In 2007, when Than Shwe's reign entered into its 15 year, he hand-picked Thein Sein to be his successor and appointed him acting prime minister. However, Than Shwe did not really fully retired after this, and still had full control behind the scene, making Thein Sein merely a leader in formality (Ku, 2015, p. 148). In November of 2010, the junta-backed Union Solidarity and Development Party (USDP) led by Thein Sein manipulated the polls and won a majority of the seats in the house of assembly. During the parliament meeting in February of 2011, head of the party, Thein Sein, was elected as president according to the Constitution of Burma published in 2008.

After Thein Sein took office as president in 2011, he led a series of reform which include the release of some political detainees, freedom from house arrest granted to Aung San Suu Kyi, the right to form political parties, and relaxation of media censorship. He also pledged to ensure fair and free elections in 2012. Hence, many scholars and observers began to think that drastic changes were happening in Myanmar, as it began to march on a path of democratic reform (Saha, 2011, p. 4). However, Thein Sein was still using military force to control various sectors in Myanmar, with military dictatorship still at the core of his power.

The aforementioned incidents clearly show that the four Myanmar junta leaders have attained their political power through anti-democratic means, such as military junta, direct appointment, or rigged elections. Under such circumstances, Myanmar society has continuously been controlled by dictatorship, with tyranny, surveillance, and suppression still imposed upon the nation's people for the purpose of solidifying the authority of the military junta. This paper will go into details on the dictatorial actions taken by Ne Win, Saw Maung, Than Shwe, and Thein Sein, and the objective is to prove that although Myanmar has been through different leaders, it has still maintained a strong military dictatorship on its society.

\footnotetext{
1 This paper was presented at IPSA's 24th World Congress of Political Science-Politics in a World of Inequality, Adam Mickiewicz University, Poznan, Poland, 23/07/2016-28/07/2016, and partial modification was done.
} 
General elections were held in Myanmar on November 8, 2015, the first open election since May of 1990. The results were as expected, with the National League for Democracy (NLD) led by Aung San Suu Kyi now holding majorities in the House of Nationalities (with 135 seats) and the House of Representatives (with 255 seats), granting NLD comprehensive governance, with NLD member, U Htin Kyaw, elected as the first Myanmar civilian president in 54 years. Aung San Suu Kyi is to head two cabinet posts including foreign affairs and president's office ministries.

However, the path ahead for the Myanmar political climate is still fraught with uncertainties, and it is mainly due to the transparent injustice embedded in the Myanmar constitution, which allows the military regime to continue to hold control over the country, reserving the possibilities for the military to make a comeback. For example, according to the Myanmar constitution, 25\% of the Parliamentary seats are reserved for the military, and changes to the constitution can only be made with over $75 \%$ approval from Parliament, meaning the military holds veto power over any proposals to alter the constitution. Moreover, important governmental posts, such as domestic affairs, national defense, and border affairs, are still appointed by the military.

Based on the above, this paper will further present on the limitations imposed on the development of democracy in Myanmar due to the terms listed in the current constitution, making it challenging for the current Myanmar government to break free from military control after the 2015 elections, with the situation resembling putting old wine in a new bottle.

\section{Ne Win's Military Junta (1962-1988)}

After Myanmar's independence, U Nu became the nation's first civilian prime minister, and under the provisions of the 1947 Constitution of the Union of Burma ${ }^{2}$, three parliamentary elections were held in June of 1951, April of 1956, and February of 1960. Even though the party led by U Nu was victorious in the elections ${ }^{3}$, the opposition party also won many seats. Because of U Nu's inability to control over half the seats in the parliament and he was compelled to pass the new budget without agreement from the parliament, Myanmar's political climate became intensely unstable by September of 1958, resulting in confrontations between the executive and legislative departments. With the nation's political operations nearly forced into a standstill, the opposing party then initiated "People's struggle" in Yangon to depose U Nu.

Due to the critical situation, an agreement was reached between $\mathrm{U} \mathrm{Nu}$ and the army and appointed General $\mathrm{Ne}$ Win to take over as a "caretaker government" for a period of six months. With military force, Ne Win restored order during this period by suppressing insurrections and riot groups and also arresting left-wing student leaders. Ne Win then seized the opportunity and positioned several key figures in the government's executive departments in order to build his own supportive base. At the end of the six-month period, he refused to give up his political authority. Although $\mathrm{U}$ Nu was able to regain power after this, he was however unable to sustain his position. He failed to effectively resolve confrontations between supporters of Buddhist pietism and secularization, minority rights, riots led by left-wing oppositions, leading to the weakening of his power

\footnotetext{
2 The drafting of this constitution was led by General Aung San, whom traveled to London several times to negotiate with the British. The British finally accepted the constitution in mid July of 1947. It is a constitution based on a cabinet system, giving the people of Myanmar more sovereignty and autonomy with a promise of Myanmar's total independence.

3 The parliamentary elections held in June of 1951 and April of 1956 were won by the Anti-Fascist People's Freedom League (AFPFL) led by $\mathrm{U} \mathrm{Nu}$. The parliamentary election in February of 1960 was won by the Union Party, which was then newly established by $\mathrm{U} \mathrm{Nu}$.
} 
foundation and disdain from the military sector (Ku, 2013, p. 361). Ne Win staged a coup d'état in March of 1962 under the pretext of political stability, which ended Myanmar's democracy that began in 1948, unfolding a military dictatorship lasting over half a century.

On the surface, Ne Win declared his antidemocratic stance on the grounds that the Myanmar society was not mature enough and to hastily implement democracy would jeopardize the country's stability (Ku, 2015, p. 70). However, due to the lack of legitimacy and legality of Ne Win's regime, the only way for him to stop opposing opinions was to use dictatorship to control the entire nation. Ne Win's dictatorial actions are as follows.

\section{Established the Revolutionary Council}

After Ne Win stepped into power, he established the Revolutionary Council comprised of 17 senior officers to replace the pre-existing civilian government and made obsolete the constitution set in 1947. The council appeared to be based on a committee system, but was actually dictated solely by Ne Win, with all opposing voices silenced. Additionally, on April 30, 1962, Ne Win issued an ideological statement called the Burmese Way to Socialism ${ }^{4}$, which served as a guide to government policies, and clearly positioned the Revolutionary Council as the nation's highest authority, which was resolved to march unswervingly towards the goal of socialism under the sole leadership of Ne Win.

\section{Established the Burma Socialist Program Party (BSPP), a One-Party State}

In order to eliminate opposing groups and take down party leaders, Ne Win banned all opposing parties in March of 1964, with all political activities stopped and dissidents arrested. At the same time, the Burma Socialist Program Party (BSPP) was declared the only legal political party, and acted as a socialist system that controlled the people. For instance, if someone wants to work as a civil servant, he will have to join first the BSPP, and in order to be promoted in the public sector, the person must first be appointed a leadership role in the party. The same rules also applied to education institutions $(\mathrm{Ku}, 2015, \mathrm{p}$. 73). In other words, joining the BSPP meant declaring you're identifying with Ne Win's military government, and it was the only way to be granted opportunities for holding important positions and to be promoted in the public sector. Furthermore, the BSPP was the only political party and the only socialist group that was allowed to exist. All socialist groups in the country were disbanded per orders of Ne Win, or were taken over by the military government, turning into groups controlled by the BSPP, and such groups including teachers association, unions, and business groups.

\section{Media and Public Opinion Censorship}

In order for Ne Win to reinforce his political power and to prevent negative news about the military government from being leaked, the Printer's and Publisher's Registration Act was announced in August of 1962, and further set up the Press Scrutiny and Registration Division according to the act, focusing on controlling all domestic and international media in Myanmar. At that time, international media were not permitted to release any press materials in foreign languages and needless to say, reports against $\mathrm{Ne}$ Win's regime were not permitted, leading to the gradual dismissal of foreign press in Myanmar. Private domestic

\footnotetext{
${ }^{4}$ The Burmese Way to Socialism is composed of the following four main components: (1) The Revolutionary Council is resolved to march unswervingly towards the goal of socialism; (2) In its activities, the Revolutionary Council will strive for self-improvement by way of self-criticism to avoid deviation towards right or left; (3) The Revolutionary Council will strive for advancement, keeping at heart the basic interests of the nation; and (4) The Revolutionary Council will critically observe, study and avail itself of the opportunities provided by progressive ideas, theories and experiences at home, or abroad without discrimination between one country of origin and another.
} 
media outlets also gradually closed down due to oppressions imposed upon them by the military government, turning Myanmar into a country without freedom of speech.

\section{New Constitution Released in 1974}

$\mathrm{Ne}$ Win repealed the 1947 constitution after he stepped into power, with the parliament also dispersed, turning the trifecta powers of executive, legislative, and judicial into the hands of the Revolutionary Council. However, his regime was still without legal foundation, and in order to make up for this constitutional deficiency, Ne Win published a new constitution in January of 1974, granting him legitimacy and legality for exercising military dictatorship. However, the constitution was composed of many absurd articles, including stating the Phithu Hluttaw as the nation's highest judicial house of assembly, with its members elected by the people every four years; however, it did not document how the representatives would be elected. Ne Win controlled Myanmar for an extensive period of 26 years, but only one election was held at the end of January 1974. With only members of the BSPP in the election, it was clear that the entire cabinet of representatives was composed of Ne Win's own people.

\section{Establishing the Council of State}

The new constitution announced by Ne Win in 1974 stated that the Central Organs of State Power was responsible for passing all national bills and tasks, and included in it were the following four councils: (1) The Council of Ministers; (2) The Council of People's Justices; (3) The Council of People's Attorneys; and (4) The Council of People's Inspection. Nonetheless, above these four councils was the Council of State that had constitutionally granted supremacy. The council was granted authorities to direct, supervise, and delegate jobs in both central and local governments; however, how the members of the council were elected and how long each term would be carried out were all not regulated, clearly showing that this organization was utilized by $\mathrm{Ne}$ Win to continue his reign of military dictatorship (Ku, 2015, p. 76-77).

The aforementioned showed that Ne Win used all kinds of measures to secure his monopoly of power to gain complete control of Myanmar. However, a series of student protests and movements in 1988 forced $\mathrm{Ne}$ Win to step down. On July 23, 1988, Ne Win announced his resignation that was nationally broadcast. The news sparked quite a commotion in the ambassador circle of Yangon and members of the international press were ecstatic, as they naively thought protests initiated by the people of Myanmar have finally caused the collapse of Asia's most rigid socialist system. However, things were not as simple as they appeared to be.

\section{Saw Maung's Military Junta (1988-1992)}

In 1988, Myanmar went through the most tumultuous political and social upheaval since its independence. The cause of the turbulence was because neighboring Southeastern nations have been on a steady path of stability in the past 40 years with continuous economic growth and improvements in lifestyles, forming a stark contrast with Myanmar. Economy in Myanmar has not improved, and on the contrary, the country has become the poorest country in Southeast Asia.

On September 5, 1987, Secretary of Union Council Sein Lwin unexpectedly announced the abolishment of large bills that were in use, and made no motion of exchanging the bills that had been abolished. This made the people of Myanmar, already one of the poorest in Asia even poorer, with $80 \%$ of currencies suddenly made obsolete and millions suddenly turned into nothing. This announcement to abolish large bills came during tuition time in Yangon, and with cash turned into useless paper overnight, protests were bound to take place in 
society. Riots were initiated by hundreds of students from Rangoon Institute of Technology, with government vehicles set on fire. Although the protests were quickly appeased by the military junta, people's dismay was on the rise (Popham, 2012, pp. 35-36).

The first wave of anti-government protest initiated by students took place in March of 1988. Fearing the protest would grow bigger with more students coming together, General Sein Lwin, who was in charge of national safety, ordered fires to be shot at those unarmed students, resulting in hundreds of casualties and fatalities. In April, people were once again enraged when the military junta applied and was listed as a least developed country by the United Nations. People were angry because they were hopeful for their country to become the most affluent in Southeast Asia after gaining independence a generation ago (Popham, 2012, p. 38). Confronted with more protests, the military junta responded with extreme violence, with hundreds of students shot to death by the army.

Faced with severe retaliation, protesting students were not deterred from their anti-government objective, and finally, Ne Win was forced to step down in mid July at the Burma Socialist Program Party meeting. As people began to see hope of returning the nation to the people, Ne Win announced "the Butcher of Rangoon", Sein Lwin, as his successor, and once again enraging the entire nation, leading to another wave of protests. Tens and thousands of students once again went on the streets of Yangon on August 8 demanding democratic reform. Seeing that the situation has gone out of control, Sein Lwin once again ordered shots to be fired at the protesting students, with Yangon falling into anarchistic chaos. In order to solve this political crisis, Sein Lwin also resigned on August 12, and appointed Dr. Maung Maung to take over, as per Ne Win's instructions. However, people were well aware that this seemingly gentle civilian president was just Ne Win's puppet, and anti-government movement was on the rise again.

Faced with such drastic upheaval, the then defense minister Saw Maung staged a coup on September 18, 1988 under Ne Win's support. Students were suppressed as extreme measures were taken to break up the 1988 uprising. The armed suppression is regarded to be the roughest military junta action since 1962, forcing Myanmar into another chapter of military dictatorship. Lacking legitimacy and legality, Saw Maung's regime was fundamentally an extension of Ne Win's military dictatorship, with the country controlled by the military junta. The characteristics of Saw Maung's dictatorial actions were as follows.

\section{Established the State Law and Order Restoration Council (SLORC)}

After stepping into power, Saw Maung's military regime was eager to restore law and order, to rebuild the country's executive institutions, and to lessen people's demands for food, clothing, and housing. Once these tasks were completed, the government promised to hold a multi-party election, and the military council would not interfere with the election in any way; power would also be passed to the winning party (Popham, 2012, p. 89). For the aforementioned, Saw Maung then formed the State Law and Order Restoration Council on November 7, 1988; however, this council was not so different from Ne Win's Revolutionary Council. On the surface, it was composed of 19 military officers that were responsible for national policies; however, it was really solely dictated by Saw Maung, and the core agenda was to reinforce the military junta and to secure Saw Maung's leadership position.

\section{Prolonged Human Rights Violations}

The military government's oppression on political dissents did not lessen during Saw Maung's reign, with people of opposing views unjustifiably arrested and detained. Saw Maung also imposed strict media regulations, 
with foreigners closely watched in Myanmar, making it difficult for the outside world to gain a complete picture of the human rights violations taking place in Myanmar. However, the information that's available is sufficient to prove the junta continued to violate human rights (Amnesty International Annual Report, 1989). ${ }^{5}$

\section{Change of the Nation's Name}

After its independence in January of 1948, the country continued to use its British colonial name, the Union of Burma. Saw Maung continued Ne Win's anti-Western capitalism ideology after he stepped into power, and thought the country should have its own name instead of using Burma that was named by the British. The country was then renamed Myanmar. The English name for the nation's capital was renamed from Rangoon to Yangon. However, the renaming of the nation was not publically discussed and people's opinions were not consulted. Many of the nation's people still prefer the name Burma (Ku, 2015, p. 123). Many scholars also argued that such action was another way for the military junta to secure its power (Pedersen, Rudland, \& May, 2000).

\section{May 1990 Election Results Annulled}

In the beginning of Saw Maung's reign, people's demand for democratic reform was on the rise. Faced with domestic and international pressures, Saw Maung was forced to hold general elections on May 27, 1990, which also consequently provided an excuse for him to establish the State Law and Order Restoration Council - the reasoning was because order must be restored before elections could be held. This gave the military government a legitimate reason to regard itself as an instigator of democracy. However, Saw Maung already predicted that the election result would not be favorable for the military junta, with releases made to the media on several occasions expressing the elections were only of symbolic and not practical significance, and the military junta was not necessarily going to turn over its power to the elected party (Foreign Broad cant Information Service, 1989a, p. 32; Foreign Broad cant Information Service, 1989b, p. 30). However, going along with the conditions at hand, Saw Maung then changed the Ne Win established Burma Socialist Program Party into the National Unity Party (NUP) and took part in the elections while he continued to monitor and suppress opposing parties' political activities, including lobbying for votes and holding campaign rallies. Leader of the opposing party, Aung San Suu Kyi, had been detained under house arrest by the military junta since July 20, 1989, forbidding her to participate in any election activities. The military junta also arrested many members of the NLD, hoping to crush the party's momentum. The military junta also believed that the people of Myanmar would abandon anything that's new and dangerous at elections and appreciate the army that had protected them from outside conspiracies and harm (Popham, 2012, p. 291). To the contrary, the NLD won by a landslide ${ }^{6}$, and for being humiliated, the Saw Maung military regime refused to accept the election results and refused to hand power to the new party, stating that a new constitution must be drafted first and the transfer of power would be made only after the drafting of the new constitution, and a halt was put on parliamentary meetings, with the State Law and Order Restoration Council continuing to be in power (Than, 2001). Saw Maung's actions once again exposed Myanmar military junta's dictatorial principle.

\footnotetext{
5 Amnesty International published a Myanmar human rights report in November 1989, consisting of several criticisms on Saw Maung's regime.

${ }^{6}$ A total of 485 parliamentary seats were supposed to be elected during these general elections, with Saw Maung's the National Unity Party (NUP) and Aung San Suu Kyi's the National League for Democracy (NLD) running for every seat. The NLD won by a landslide, winning 392 seats $(80.82 \%)$, and the NUP only won 10 sets $(2.06 \%)$, with the remaining seats won by other political parties.
} 
However, when the military junta nullified the May 1990 election results, people of Myanmar's anti-military government sentiments once again reached an all time high. With pressures and condemnations both locally and internationally, Saw Maun was finally forced to resign on April 23, 1992, turning over his power to his successor, General Than Shwe.

\section{Than Shwe's Military Junta (1992-2010)}

Than Shwe was appointed by Saw Maung to step into power without people's consensus, therefore, his regime also lacked legitimacy and legality. To maintain power, Than Shwe continued to rule through military dictatorship. His dictatorial actions were as follows.

\section{Selected Parliamentary Representatives at His Own Will}

In order to appease public rage sparked by the military government's nullification of the May 1990 election results, after stepping into power, Than Shwe publically announced a National Convention will be held in January of 1993, but the cabinet consisted of delegates that he had selected and were not openly elected. Out of the 700 delegates, there were only 156 seats that were elected from the May 1990 elections, with the rest newly appointed by Than Shwe. Moreover, although 392 seats were won by the NLD during the May 1990 elections, only 90 were selected to attend the convention, leaving out many democratically elected representatives. Clearly, this parliamentary meeting was not representative of the people, and its sole agenda was for the military junta to create a false illusion of legality.

\section{Forcibly Interfering with Parliamentary Meeting Operations}

Under Than Shwe's strongman leadership style, opposing parties had nearly no opportunities to speak up during the National Convention. The NLD was quite upset about the situation, and collectively left the convention in 1995 in sign of protest. With no opposing voices, the convention ran according to Than Shwe's plan, and a new constitutional framework that favored the junta was passed on September 3, 2007. The framework clearly stated that: (1) The constitution would require that future presidents of Myanmar must have the ability to handle high-level military affairs; (2) Parliamentary candidates for each religion/district shall be appointed by the military commander in that region; (3) Military officers shall be appointed to serve in each executive department; and (4) In situations of violent threat or segregation, chief military commander has the power to intervene (Kyi, 1994). Finally, a forced referendum was carried out under strict surveillance of the junta to pass this new constitution in May of 2008. Considered as Than Shwe's way to pave the road for the parliamentary election to be held in November of 2010, this was actually carried out to legalize the junta and for the military to continue to dictate Myanmar (Egreteau, 2014).

\section{Leading the State Peace and Development Council (SPDC)}

After stepping into power, Than Shwe renamed the State Law and Order Restoration Council founded by Saw Maung to the State Peace and Development Council. The council was also led by Than Shwe, whereby a personnel restructuring was implemented, with most of the council members composed of military officers between 40-50 years of age. Although General Khin Nyunt was appointed as prime minister by Than Shwe in August of 2003, Than Shwe remained suspicious of Khin Nyunt whose ascent was attributable to Ne Win. In October of 2004, Khin Nyunt and his subordinates were charged, and Khin Nyunt was arrested with a 44-year suspended jail term on corruption charges (Jagan, 2006). After Khin Nyunt was ousted, Than Shwe then appointed General Soe Win to take over, the latter retired after three years due to health reasons. In October 
2007, Than Shwe appointed Thein Sein from his party to take over the prime minister's position, who later went on to become president. The aforementioned shows that during the time of Than Shwe's power, he single-handedly dictated personnel restructuring of high-ranked officers and manipulated conflicts between different groups, and he also never considered giving up his power.

\section{Cracked Down on the Buddhist Revolution}

Because of the junta's prolonged control over import trade policies, Myanmar's economy continued to be lackluster during Than Shwe's reign, and the government even inhibited developments of private corporations and monetized trade deficits, resulting in inflations and currency instability. In mid August of 2007, Than Shwe removed subsidies on fuel, similar to Ne Win's unexpected abolishment of large currency bills in 1987, causing petrol and diesel prices to increase by $66 \%$ and the price of compressed natural gas for buses to increase by five times in a week. The prices of commodities then also increased considerably, making the lives of the underprivileged even more unbearable (Rogers, 2012, p. 173). On August 19, 2007, protests against the removal of subsidies were beginning to take place in Yangon, which were led by some members from the 1988 student movement; however, the military responded with fast and ferocious force, and the protestors were quickly arrested. Then, on September 18, thousands of Buddhist monks began to join the protest and were at the forefront of the demonstrations. Foreign media then referred to the protest as the "Saffron Revolution", connecting to the saffron-colored robes worn by Buddhist monks and waistbands of the same color worn by other protestors. Over tens and thousands of monks had joined in the protest by September 24 in Yangon (Rogers, 2012, p. 176). However, faced with such mass-scale demonstration, Than Shwe's junta still refused to change its ways, and instead, military and police forces were ordered to raid monasteries and fired at crowds of peaceful protestors of monks, resulting in great conflicts in Myanmar's supposed Buddhist-oriented society, and people once again got a clear picture of the authoritarian nature of the military junta.

From the aforementioned, it is clear that Than Shwe continued to rule through military dictatorship, following the footstep of Ne Win since 1962. However, Than Shwe was also aware that the military was in dire need to become a government of legitimacy and legality, which had to be done with parliamentary representatives elected from general elections. In other words, elections are helpful in shaping the legitimacy and legality of a governing system. Therefore, the military junta placed utmost priority in holding a parliamentary representative election in November 2010 according to the constitution published in 2008.

\section{Thein Sein's Military Junta (2010-2016)}

On March 8, 2010, election laws were announced by Myanmar's military ruling council, the State Peace and Development Council, with 17 delegates appointed to form an election committee that would carry out the general election on November 7, 2010. Since he appointed Than Shwe as prime minister in 2007, Thein Sein also directly took part in political reform activities, including constitution referendum, house of representative election, state opening of parliament, and presidential election.

In order for the military junta to gain legitimacy, on 26 April 2010, Thein Sein resigned his military posts to run as civilian in the general elections. He then formed the Union Solidarity and Development Party (USDP) to compete against other political parties. These actions seemed to show the military junta's willingness to carry out democratic reform, but its actual actions showed otherwise. The general election was completely controlled by the military, leading to scholars claiming that it was "a rigged election" (Englehart, 2012). 
Nominally, the Myanmar military junta had opened the election to all political parties, but it was actually a way for it to gain control over them, including obtaining lists of their leaders, important officers, campaign strategies, and details on their activities. Some scholars have also provided evidence to prove that this was closed, unfair, and unjust, and it was carried out for the USDP formed by the junta to win the house of representative election and for the junta to continue to be in control (Ku, 2015, pp. 153-163).

First of all, political parties had to register for the election in accordance to the election laws announced by the junta in March 2010, and all the parties intending to run in the November 2010 general election had to register within 90 days. After the registration was approved, a party leader had to be elected within 30 days. For the opposing parties, the 30-day deadline was quite rushed, and it was quite challenging to complete these administrative terms and procedures within the given time due to Myanmar's wide geographical regions and underdeveloped transportation and information systems. Secondly, the election committee also required that all campaign related activities had to be applied seven days prior to the events, with supplementary information also required, including assembly time, location, number of participants, event duration, the names and identification numbers of the speakers. These requirements all worked against the opposing parties, with the junta using time constraint to make running their campaigns more difficult. Thirdly, the new election laws also prohibited criminals from joining political parties, and those with criminal records were not permitted from taking part in the election, even if the said person was the leader of the party, making Aung San Suu Kyi and other socially prominent figures from the opposing side ineligible as election candidates. The NLD led by Aung San Suu Kyi knew that the election was tainted with political conspiracies by the military junta, and publically announced on March 29, 2010 that it will not register to contest in the election.

Moreover, the junta's most obvious sham was by imposing strict control on the votes, with employees of public sectors (including the Red Cross and fire departments) forced to vote for the USDP and votes in areas in Yangon where opposing parties had higher chance of winning were rigged to favor the ruling party (Popham, 2012, p. 5). On September 16, 2010, claiming safety concerns, the junta unexpectedly shut down voting stations in 3,400 villages resided by five minority groups (Kachin, Kayah, Kayin, Shan, and Mon), and the majority of these minorities were supporters of the opposing parties. On October 18, 2010, the junta declared that foreign media were not allowed in Myanmar and all media's visa applications were rejected (Popham, 2012 , p. 5). Strict regulations were also imposed on domestic news outlets, with inspections required for all election related releases prior to publication. However, the USDP and the National Unity Party - another party with close military ties - were given exclusive rights to advertise on national media (Ku, 2015, pp. 158-159).

Finally, under the junta's close control, the general election in November 2010 unfolded according to the military's plan and the $\mathrm{USDP}^{7}$ won with seats reserved for the military as stated in the 2008 constitution $^{8}$, the junta controlled over $80 \%$ of the seats in the House of Nationalities (or National Assembly) and the House of Representative (or People's Assembly). In February 2011, Thein Sein was elected as the first president of the Republic of the Union of Myanmar during a meeting held by the newly established parliament.

\footnotetext{
7 The Union Solidarity and Development Party, which represents the military, won 129 seats out of the 224 seats in the House of Nationalities (or National Assembly) and 259 seats out of the 440 seats in the House of Representative (or People's Assembly).

8 According to the 2008 constitution, 56 seats out of the 224 in the House of Nationalities shall be reserved for the military, and 110 seats out of the 440 seats in the House of Representatives shall be reserved for the military. In other words, a quarter of the seats in the Union will be composed of personnel from the military.
} 
Nonetheless, the way that Thein Sein attained his leadership position was from a noncompetitive election, which was manipulated heavily by the junta, making his regime still lacking in full legitimacy (Turnell, 2001). After he stepped into power, although a series of reform and opening-up policies have been implemented, in actuality, military force is still at the core of the governance, controlling Myanmar from all aspects as listed below.

\section{Military Control of the Assembly of the Union (Phithu Hluttaw)}

According to the 2008 constitution, the Assembly of the Union is Myanmar's highest legislative institution, with rights of presidential election. In other words, it is the most important political institution in Myanmar, with the structure of its members reflective of Myanmar's current political conditions. After the November 2010 general election, $80 \%$ of the seats in the Union's are held by military officers or parties connected to the military, representing interests of the junta and the backbone of Thein Sein's power, with full control over policy making and budget delegations. On the contrary, other opposing parties are put in very weak positions with no supervising power over policies or room for partaking in policy making.

\section{Military Control Over Executive Rights}

According to the 2008 constitution, division or state chief ministers shall be elected through voting, and are usually held by leaders from the majority party in each division or state. ${ }^{9}$ In other words, division or state chief ministers should be the highest executive authority in that region or state, but it is not the case in actual practice. According to the constitutional framework passed in 2007, each division (state) military commanders can appoint military officers to work within various governmental institutions, making the military commander in each division (state) the most influential figure in that region. Moreover, publically elected executive officers (ministers) lack executive experiences and support system; therefore, without the assistance from military commanders to provide executive resources, it would be very difficult for publically elected ministers to serve their purpose effectively. This is how Thein Sein is able to openly use his military power to control the executive systems in each division (state).

\section{Military Control Over Media and Public Opinion}

Although Thein Sein has begun loosening media control after he stepped into power, including abolishing press censorship, lifting Internet use restrictions, opening up private newspapers, however, media in Myanmar still do not enjoy absolute freedom. In March 2013, Thein Sein announced an executive order limiting press freedom, forbidding criticism of the state for the sake of preserving national unity, which includes no criticisms against the amendments made towards the constitution in 2008. Moreover, compared to private newspapers, the military has far better resources to support its own publications; therefore, private newspapers can only be distributed in few major cities in Myanmar, but military-supported media publications are able to reach far into remote rural areas, resulting in the majority of the people in the bottom-tier are only exposed to reports related to the USDP (Ku, 2015, p. 185).

\section{Military Oppression on Ethnic Minorities}

Thein Sein has overlooked dismays and demands of Myanmar's ethnic minorities after he became president, with minority groups being treated with brutality and oppression, and Myanmar's civil war has

\footnotetext{
9 According to the 2008 constitution, the entire nation of Myanmar is divided into six divisions and seven states. The seven divisions are largely inhabited by the Bamar (Burmans) and ethnic minorities inhabit the seven states.
} 
resulted in countless refuges fleeting overseas. This has resulted in negative impacts for Myanmar and its neighboring countries, with Myanmar condemned by the international community. First of all, Thein Sein neglected the ceasefire agreement after becoming president and launched large-scale military attacks on the Kachin Independence Organization (KIO) (Liberty Times, 2015, January 19); secondly, Thein Sein also continued to attack the Kokang Chinese in Shan State (Liberty Times, 2015, February 17); and thirdly, attack was launched on the Democratic Karen Benevolent Army in order to expand control over the Salween River and to restart the Hat Gyi Dam project, which has been suspended for years due to the civil war (Burma Rivers Network, 2014); lastly, the military did not try to resolve violent confrontations between Arakan Buddhists and Rohingya Muslims, and with information blocked off, mass arrests have been made against the Muslims with them violently mistreated (Ku, 2015, pp. 197-198). From the aforementioned cases on Myanmar's ethnic minorities, it is clear that the way that Thein Sein deals with ethnic minority issues is no different from the nation's previous leaders, showing that his open reform policies are not exactly all encompassing.

Based on the above, under superficial legitimacy, Thein Sein still relies on military force to control Myanmar's parliamentary institutions, executive systems, media and public opinions, and ethnic minorities. This leads us to stipulate that so called reforms and political openness are nothing but the tip of the iceberg. In reality Myanmar is still victim of military rule and dictatorial regime.

\section{The Uncertainties After Myanmar's 2015 General Election}

General elections were held in Myanmar on November 8, 2015, with the elections considered by many on the outside to be the first free election since May of 1990. Besides 25\% of the seats composed of personnel from the military, each electoral district in Myanmar appointed representatives to run in the elections, resulting in 168 seats in the upper house (the House of Nationalities)and 330 seats in the lower house (the House of Representatives). As expected, the people of Myanmar used their votes to express their dismay for the long-term military authoritarian rule, with Aung San Suu Kyi's the NLD winning 135 seats in the upper house and 255 seats in the lower house, and the military's USDP gaining only 12 seats and 30 seats. NLD won parliamentary majority, making it the biggest party in Myanmar with absolute majority.

U Htin Kyaw and Henry Van Hti Yu of NLD were respectively nominated by the lower and upper houses as presidential candidates, and successfully became the first democratically elected civilian president and second vice president since 1962. Furthermore, although barred from running for president by the Myanmar constitution, Aung San Suu Kyi is to head two cabinet posts including foreign affairs and president's office ministries, and may directly participate and even lead the making of important national policies in the future. Under such conditions, international communities are generally optimistic about Myanmar's post-election political stability and foresee a gradual demise in the military's influence.

However, this study suspects that Myanmar's political development may not be completely smooth sailing from now on and may still experience some uncertainties. This is partially due to the unresolved conflicts with ethnic minority groups, with violent confrontations still unfolding, but the main reason is because throughout the military's over five decades of authoritarian rule, it has used its political advantages to implement various benefits in the Myanmar constitution to ensure that it can sustain its power, resulting in the continuation of the junta's influence under unreasonable constitutional protection even after the peaceful turnover of political power after the 2015 elections. 
According to Myanmar's constitution, firstly, 25\% of parliamentary seats must be reserved for the military, and the constitution can only be changed with agreement from more than $75 \%$ of the parliamentary representatives. In other words, the military holds control over amendments on the constitution. Secondly, in regards to the presidential election, the presidential and vice presidential candidates have to be elected by the Presidential Electoral College, which consists of three separate committees from the House of Nationalities, the House of Representatives, and military-appointed members of parliament, giving the military a clear advantage with presidential candidacy. Thirdly, the Myanmar constitution states that the ministers of defense, home affairs, and border affairs should also be drawn from the ranks of the military, meaning that regardless who is elected as president, the right to appoint ministers that are in charge of national security is still controlled by the military. Fourthly, the military has the legal right to declare and take over during a state of emergency. The highest military authority has the right to take over and control the country whenever the nation is in a critical situation that endangers the lives or properties of the people or causes the state to fall apart. Simply put, this clause in the constitution allows the military to rationalize coup d'etat and to hold legal support for seizing control (Yang, 2015).

The aforementioned shows the imbalance of power with the constitution of Myanmar, and despite the NLD led Aung San Suu Kyi winning parliamentary majority in 2015 and the elections regarded by international press to be free and open, the transparent injustice observed in the Myanmar constitution still may become the tipping point between the new ruling party and the conservative military power, reserving future possibilities for the military to make a counterattack.

\section{Conclusions}

Since Myanmar's access to independence in 1948, its course of political development has been faced with countless obstacles. During the initial stage of its independence, although it went through a period of representative democracy, the government led by $\mathrm{U} \mathrm{Nu}$ was unable to resolve its domestic problems, nor did it succeed in bringing stability and prosperity to its people. Therefore, Ne Win's junta was able to quickly replace the civilian government.

Through military force, Ne Win took over by staging a coup d'état, with him ruling the country for an extensive period of 26 years. During his reign, he led the Revolutionary Council and enforced a one-party government with the Burma Socialist Program Party. Furthermore, to achieve legitimacy and legality for his military junta, Ne Win also single-handedly announced a new constitution in 1974 and also established the Council of State to reinforce his authoritarian government.

Saw Maung was supported by Ne Win to stage a coup d'état to continue Ne Win's dictatorial government. He also established the State Law and Order Restoration Council that was similar to the Revolutionary Council, with the agenda of consolidating the leadership position of the military junta. Saw Maung also continued to arrest and detain political dissidents and showed disregard to human rights in Myanmar. He also denied the result from the May 1990 election whereby the junta lost. By refusing to give his political power to the newly elected parliament, the junta showed its stubborn authoritarian nature.

Saw Maung appointed Than Shwe to succeed him as leader of Myanmar, and in order to sustain political power, Than Shwe not only single-handedly manipulated conflicts between different parties in the military, he also selected parliamentary representatives at his own will, instead of holding open elections. He also forcibly interfered with operations of the parliament and passed a constitution in 2008 that favored the military. Faced 
with protesting crowds in the Saffron Revolution, instead of reflection on his own actions, Than Shwe ordered military and police forces to attack unarmed monks and people, clearly showing the junta's lack of consideration for change.

With the support from Than Shwe, Thein Sein stepped into power in 2011 through a rigged election. Although many open reform policies have been implemented since he has gained control, the military is still in full control of the assembly of union, dictating policy-making and budget control. Military commanders are in control of executive systems in every division (state), and military resources are delegated to that press that favor the junta, with private media sanctions. Ethnic minorities are also brutally suppressed.

This paper shows that the four political turnovers led by Ne Win, Saw Maung, Than Shwe, and Thein Seinall lack legitimacy and legality, resulting in dictatorial control over Myanmar that sees a change in form but not in content. Whether the conservative military power is willing to amend the 2008 constitution was a critical topic of discussion for the nation-wide election held in Myanmar on November 8, 2015, especially for issues pertaining to national leader qualifications and the controversial requirement that demands $25 \%$ of parliamentary seats to be reserved for the military ${ }^{10}$. However, by altering specifications listed for national leader qualifications, which will allow Aung San Suu Kyi to run for president of Myanmar, or to abolish military reserved seats in the parliament, will both bring critical impacts to the military's existing authority and interests, which is why the military ultimately did not agree to constitution amendments. Lastly, as mentioned, albeit the NLD led Aung San Suu Kyi winning parliamentary majority in 2015 and holds absolute majority, the embedded transparent injustice in the Myanmar constitution still gives the military advantages for continuing and reinforcing its power. In other words, the military has yet to show any plans for relinquishing its power, making further reform in Myanmar quite challenging without collaboration and compromise from the military. The existence of the unique institution of military rule in Myanmar makes the situation resembling putting old wine in a new bottle.

\section{References}

Amnesty International Annual Report. (1989). Retrieved from https://www.amnesty.org/en

Burma Rivers Network. (2014, November 7). New report documents recent violent conflict in Karen State (in Chinese). Retrieved from http://burmariversnetwork.org/index.php/dam-projects/salween-dams/dagwin

Egreteau, R. (2014). The continuing political salience of the military in post-SPDC Myanmar. In N. Cheesman, N. Farrelly, \& T. Wilson (Eds.), Debating democratization in Myanmar (pp. 265-266). Singapore: ISEAS.

Englehart, N. A. (2012). Two cheers for Burma's rigged election. Asian Survey, 52(4), 666-686.

Foreign Broad cant Information Service. (1989a). Daily Report/East Area, 2 June, 1989.

Foreign Broad cant Information Service. (1989b). Daily Report/East Area, 15 November, 1989.

Heywood, A. (2009). Politics (in Chinese). (J. C. Yang, P. Y. Li, W. B. Lin, \& C. L. Liu, Trans.). Taipei County: Weber Publication (in Chinese).

Jagan, L. (2006). Burma's military: Purges and coups prevent progress towards democracy. In T. Wilson (Ed.), Myanmar's long road to national reconciliation (pp. 29-30). Singapore: ISEAS.

Ku, S. C. Y. (2013). Southeast Asian governments and politics: Persistence and change (in Chinese). Taipei: The Commercial Press.

Ku, S. C. Y. (2015). 50 years of military dictatorship in Myanmar (in Chinese). Singapore: World Scientific Publishing.

\footnotetext{
10 Article 59 of Myanmar's constitution states the country's presidency shall be elected by the house of representatives, and bars anyone with a foreign spouse or children from the country's presidency. Aung San Suu Kyi's late husband was British, as are her two sons, and thus disqualifying her for presidency.
} 
Kyi, K. M. (1994). Myanmar: Will forever flow the ayeyarwady? Southeast Asian Affairs 1994, 209-230. Singapore: Institute of Southeast Asian Studies.

Liberty Times. (2015, January 19). Fighting intensifies in Northern Burma, over 1000 civilians trapped in war zone (in Chinese). Retrieved from http://news.ltn.com.tw/news/world/breakingnews/1209263

Liberty Times. (2015, February 17). Civil war breaks out in Kokang Myanmar, countless refugees flee their homes (in Chinese). Retrieved from http://news.ltn.com.tw/news.world/breakingnews/1236911

Pedersen, M. B., Rudland, E., \& May, R. J. (2000). Burma-Myanmar: Strong regime, weak state? London: C. Hurst and Co.

Popham, P. (2012). The life of Aung San Suu Kyi (in Chinese). (A. Ch. Chuang \& Zh. G. Fan, Trans.). Taipei: Linking Publishing.

Rogers, B. (2012). Burma: A nation at the crossroads. London: Rider.

Saha, S. R. (2011). Working through ambiguity: International NGOs in Myanmar. (Cambridge: the Hauser Center for Nonprofit Organizations at Harvard University.

Than, T. M. M. (2001). Myanmar military in charge. In J. Funston (Ed.), Government and politics in Southeast Asia (p. 207). Singapore: ISEAS.

Turnell, S. (2001). Myanmar in 2010: Doors open, doors close. Asian Survey, 51(1), 148-154.

Yang, A. H. (2015). The fragile transformation of disciplined democracy: Implication of Myanmar's 2015 general election. Wenti Yu Yanjiu, 54(4), 158. 